\title{
THE IMPLEMENTATION OF LITERACY CULTURE PROGRAMS IN ELEMENTARY SCHOOL
}

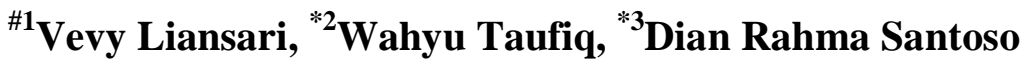 \\ ${ }^{\# 1}$ English Lecturer, Primary Teacher Education Study Program, Universitas Muhammadiyah \\ Sidoarjo, Indonesia \\ ${ }^{* 2}$ English Lecturer, English Education, Universitas Muhammadiyah Sidoarjo, Indonesia \\ ${ }^{* 2}$ English Lecturer, English Education Study Program, Universitas Muhammadiyah Sidoarjo, \\ Indonesia
}

Corresponding Author Email: vevyliansari@umsida.ac.id

\begin{abstract}
A B S T R A C T S
This study aims to describe the implementation of literacy culture programs of elementary school. This study used phenomenology of a qualitative approach. The subjects were the headmaster, teachers, students who were selected by using purposive sampling technique. The validity data test used triangulation techniques by comparing the results of observations, interviews, and documentation. The results showed that: 1) The policy for implementing a literacy culture at elementary school by using the School Literacy Movement program of the government. It is based on Permendikbud No. 23, 2015 focusing on character development. (2) The implementation of literacy culture of elementary school. It is based on the habituation stage that carried out 10 minutes of reading Al Qur'an and storybooks before lessons. The development stage of the activities carried out the respond to the contents of reading books by reading independently, giving appreciation for student literacy achievements, and having a school literacy team. The learning stage is by getting used to reading textbooks and using various strategies that support learning.
\end{abstract}

\begin{tabular}{l}
\hline A R T I C L E I N F O \\
\hline Article History:
\end{tabular}

Received: December, 2021

Revised: December, 2021

Published: December, 2021

Keywords:
Implementation,
Literacy Culture,
Elementary School

Keywords:

Elementary School

How to cite: Liansari, V., Taufiq, W., \& Santoso, D. (2021). The Implementation of Literacy Culture Programs in Elementary School. Jo-ELT (Journal of English Language Teaching) Fakultas Pendidikan Bahasa \& Seni Prodi Pendidikan Bahasa Inggris IKIP, 8(2), 189-197. doi:https://doi.org/10.33394/joelt.v8i2.4481

\section{INTRODUCTION}

Students' literacy skills are a crucial need in the 21 st century. Even in the World Economic Forum report, it is stated that there are three primary skills needed, including foundation literacy, competence related to problem-solving, and character qualities (WEF, 2016:8). Foundation literacy is considered to be the main ability of a student in everyday life. The function of skills is the main basis for creating more advanced competencies. This category includes not only reading and numeric literacy, but also scientific literacy, ICT (Information and Communication Technology) literacy, financial literacy as well as cultural literacy and citizenship. In fact, this ability is closely related to the demands of reading skills which lead to the ability to understand information analytically, critically, and reflectively. 
Literacy is known as a person's ability to process and find information when reading and writing. In its development, the term literacy always changes according to the challenges of the times. In the past, the definition of literacy was defined as using the ability to read and write. Now, literacy has been used in a broader sense. It has penetrated into cultural practices related to social and political issues. Literacy culture is a way of thinking that is followed by a process of reading, writing and finally what is done in the activity process will produce works (Harjatanaya, Chysta, \& Islamy, 2018: 44). The results of PIRLS (Progress in International Reading Literacy Study) in 2011, PIRLS or Progress International Reading Literacy Study (PIRLS) ) evaluates the reading ability of fourth-grade students. Indonesia is ranked 45th out of 48 participating countries with a score of 428 , while the average score is 500. INAP or the Indonesia National Assessment Program (INAP) or the Indonesian Student Competency Assessment (AKSI) evaluates students' abilities in reading, math, and science. INAP/AKSI is aligned with PIRLS because they are the same for grade IV elementary schools. The results of the AKSI show that the ability in the less category is $77.13 \%$ for mathematics; $46.83 \%$ for reading, and $73.61 \%$ for science. The category enough is $20.58 \%$ for mathematics; $47.11 \%$ for reading; $25.38 \%$ for science. The good category is $2.29 \%$ for mathematics; $6.06 \%$ for reading, and $1.01 \%$ for science.

In 2011, UNESCO released the results of a reading culture survey of residents in ASEAN countries. The fact shows that Indonesia's reading culture is at the lowest rank with a value of 0.001. It means that out of about a thousand Indonesians, only one still has a high reading culture. In Indonesia, there is still a phenomenon of intellectual unemployment because people's interest in reading is still low.

Written in the Program for International Student Assessment (PISA) in 2009, Indonesian students were ranked 57th (out of 65 participating countries) with a score of 402 (OECD average score of 493), while PISA 2012 showed that Indonesian students were in the 64th with a score of 396 (OECD mean score of 496). The 2015 PISA results got a score of 397. Between 2012 and 2015, student achievement improved albeit slightly. The reading ability of Indonesian students is still very low. The latest PISA results in 2018 have decreased compared to 2015, the reading ability category of Indonesian students is ranked 74th (out of 79 participating countries) with a score of 371 (OECD average score of 489).

Therefore, these results still illustrate that educational institutions in Indonesia have not been maximal in accommodating students' learning interests, especially reading and writing as learning needs. This results in low interest in lifelong learning in Indonesian society. Worse, this has not been accommodated since an early age under 15 years, as indicated by the low awareness of literacy education in elementary schools.

Literacy culture plays an important role in the progress of a society. The low ability to read will have a negative impact on one's self-development and performance, which in turn will have a negative impact on the development of the nation. This is because the low interest in reading results in the individual not being able to know and follow the development of science and information. A person's habits are not something that is natural from humans, but the process of achieving permanent results in the form of appreciation of all the knowledge and skills obtained through education so that the individual concerned can do or do something that is beneficial to his life or the lives of others. Literacy culture is a habit of thinking that is followed by a process of reading, writing, and supported by a conducive environment (Rostiawati, 2017: 4). It is not easy to cultivate a literacy culture, it requires a strong commitment. This can be started with the habit of reading books, by seeking a supportive environment. The literacy culture embedded in the younger generation will affect the level of success both at the education level and also in social life (Suragangga, 2017:157). In the view of Kellner \& Share, (2009:5), literacy is related to using the acquisition of skills and knowledge to read, interpret and compose types of texts and exclusive artifacts and to 
acquire the tools and intellectual capacity so as to be able to participate fully in society and its culture. Through the strengthening of literacy culture, the quality of education can be improved as a result can increase the quality of human resources. Long life education (long life education) can also be realized by strengthening the literacy.

Educational institutions need to be a major concern for the government in institutionalizing this literacy culture. Education as a means of shaping the future of a nation plays an important role in realizing a society that is culturally literate. It is through education that we can transfer values from the old generation to the new generation. The values of reading and writing are appropriate and should be conveyed and implemented in education. Reading and writing skills are very important for a student. Reading skills are needed to enrich insight, vocabulary, and points of view in understanding the situation. While writing skills are needed to express ideas and arguments. Education must be able to foster interest in students to read and write. The government9 through the Ministry of Education and Culture is promoting a School Literacy Movement program that involves stakeholders in the field of education. However, in practice, not all policymakers understand correctly about the School Literacy Movement.

Educational institutions need to be a major concern for the government in this literacy culture. Education as a means of shaping the future of a nation plays an important role in realizing a literate cultured society. Through education, we can carry out the process of transferring values from the old generation to the new generation. The values of reading and writing are appropriate and should be conveyed and implemented in education. Reading and writing skills are very important for a student. Reading skills are needed to enrich insight, vocabulary, and points of view in understanding the situation. While writing skills are needed to express ideas and arguments. Education must be able to foster interest in students to read and write. The government through the Ministry of Education and Culture is promoting a School Literacy Movement program that involves stakeholders in the field of education. The School Literacy Movement was developed based on Permendikbud Number 23 of 2015 concerning the growth of character in children (Harjatanaya et al., 2018:15). The general goal of this school literacy movement is to make students have the habit of reading and writing, so that students become lifelong learners (Kemendikbud, 2017: 6). This activity will also have an impact on student learning outcomes. This movement does not only involve students, but is a comprehensive effort that involves all school members, be it teachers, parents/guardians, and the community as part of the education ecosystem. However, in practice, not all policymakers understand correctly about the School Literacy Movement. Guidelines on the school literacy movement have also been distributed to every school in Indonesia to be implemented, one of which is at elementary school.

Through schools, literacy culture can also be embedded in the curriculum used. Although its implementation in schools as a place to seek knowledge has not been fully maximized in cultivating a culture of reading and writing or it is said to be a literacy culture, at least the literacy culture has been instilled from an early age and its implementation can be measured. This literacy culture program at elementary school is realized so that students have high reading habits, and are able to understand what they have read, and are able to apply it in daily life. From the results of interviews with school headmasters, literacy is carried out, but it is not optimal and socialization is still ongoing. From observations made by researchers, it can be seen that every child has a different interest in reading, when the school recess bell rings, it can also be seen that most students choose the school canteen as a place to spend break hours rather than the library. The absence of special education personnel who guard the library makes students only play in the library and do not read books. Even so, the school continues to implement the literacy culture in the classroom and continues to develop 
libraries and other infrastructure facilities to support the actualization of the literacy culture program.

Based on the explanation above, the implementation of the 2013 curriculum also requires literacy activities before carrying out the learning process. These literacy activities are carried out so that students and teachers make reading culture an important activity for life. Literacy culture has a positive influence on students and teachers. The importance of literacy skills, apparently not in accordance with the conditions of learning in schools today. Conditions in the field indicate that schools as a place to seek knowledge have not fully grown a culture of reading and writing or it is called a literacy culture. Literacy culture which should be a part of students' self-development has not been cultivated in schools. This can be seen when the school recess bell rings, most students choose the school canteen as a place to spend their break rather than the library. Students are also less interested in reading nonsubject books. Therefore, researchers want to know the extent of the implementation of literacy culture activities in SD Zainuddin, Ngeni.

\section{RESEARCH METHOD}

This study uses a qualitative research approach. It means that to explore and understand the meaning of a phenomenon from a number of individuals and groups of people. The researcher observes the condition of the object directly. Data collection techniques using triangulation (combined), data analysis is inductive and qualitative research results emphasize meaning rather than generalization.

\section{Research Design}

This study uses phenomenology type. A phenomenology study is an exploration of a system that is tied to an event that can be studied as an object of study. It is a series of scientific activities carried out intensively, in detail, and in-depth about a program, event, and activity, both at the individual level, group of people, institutions to gain in-depth knowledge about an event. In this study, a phenomenon that occurred in elementary schools related to the implementation of a literacy culture was carried out as an effort to improve students' critical thinking skills.

\section{Subject}

The subjects of this study were the headmaster, the teachers, and fifth grade students. The object of this research is everything related to the implementation of literacy culture programs in SD Zainuddin, both in the context of perceptions, activities, and all things about the behavior of school people.

\section{Instruments}

In this research, researcher used observation guidelines, interviews, and questionnaires to measure the implementation of literacy culture programs at SD Zainuddin Ngeni. The following are the guidelines for the instruments used: (1) Observation sheet is used to observe the process of activities and record information during research on the implementation of literacy culture; (2) The interview guide was used to dig up information to the informants. The resource persons in this study were the the headmaster, the teacher of fifth grade, and 22 students of fifth grade. The questions in this study were about the implementation of school literacy culture; (3) Questionnaire guide aims to obtain information from respondents about school literacy culture by students, namely statements that describe literacy conditions in schools. From the statement answered, it describes how much literacy culture has been implemented. 


\section{Data Analysis}

Activities in qualitative data analysis are carried out interactively and take place continuously until complete so that the data is saturated. Data analysis in this study was carried out during data collection, and after completion of collection within a certain period of time. At the time of the interview, the researcher analyzed the answers of the interviewees. If the answer is deemed unsatisfactory, the researcher conducts interviews again to a certain stage. For the data analysis technique, the Miles and Huberman analysis technique is used which is divided into three stages, namely the data reduction stage, the data presentation stage, and the conclusion/data verification stage (1994: 10). (1) Data Reduction, reducing data means doing summarizing activities, choosing the main things, focusing on the important things, looking for themes and patterns and discarding unnecessary ones. Therefore, the data which is reduced gives a clear picture, makes it easier for researchers to carry out further data collection, and look for it if needed. At this stage the researcher reduces the data by: transcribing the results of documentation, observations, interviews, and questionnaires as a whole obtained from students as the main source, as well as headmasters, teachers as supporting data. After transcribing the data from the field, the researchers analyzed the data related to the data to be obtained, namely about the implementation of literacy culture programs at SD Zainuddin Ngeni. the lasy is by grouping the data according to its type, in this case grouping the analyzed data to get the success factors and obstacles in the implementation of literacy culture programs at SD Zainuddin Ngeni; (2) Data Display, the presentation of data in qualitative research most often uses descriptive text. By presenting data, it is easier to understand what happened and can plan further activities based on what has been understood. In this case, it describes and categorizes the indicators of literacy culture programs and then analyzes how the implementation of literacy culture programs in SD Zainuddin Ngeni with the theory in the literature review. Then, it is based on the results of observations, questionnaires, and reinforced by the results of interviews with students as the main source and supported by the headmaster and the teacher; (3) Drawing conclusions, at this stage, the researcher uses the results of the analysis at the data presentation stage to describe the implementation of literacy culture programs at SD Zainuddin Ngeni. Drawing conclusions based on data from several instruments that have been given to the subject.

\section{RESEARCH FINDINGS AND DISCUSSION Research Findings}

\section{Policy on Implementation of Literacy Culture Programs at SD Zainuddin Ngeni}

SD Zainuddin Ngeni is one of the schools that implements a literacy culture programs. The literacy program is guided by the Government's School Literacy Movement which has been running at the stage of habituation, development, and learning. From the results of the interview with the headmaster, literacy implementation at SD Zainuddin Ngeni began to be carried out in the 2017/2018 school year since the government launched the literacy movement program. The main purpose of literacy culture in this school is to foster interest in reading. In addition, creating a text-rich environment by improving the library and providing supporting facilities along with a collection of reading books. Efforts made by SD Zainuddin Ngeni to create a social and affective environment as a model of literate communication and interaction, namely by forming a school literacy team, and dividing each task for each teacher such as the person in charge, handling the problem of borrowing books, and coordinating the results of student literacy work. Schools are trying to implement the regulations made by the Ministry of Education and Culture of the Republic of Indonesia regarding Decree No. 23 of 2015 concerning the growth of character in schools through habituation, one of which is 
through mandatory reading activities 10 minutes before learning to read books other than subject books (Kemendikbud, 2019:7).

\section{Implementation of Literacy Culture Programs at SD Zainuddin Ngeni}

There are three stages in the implementation of literacy culture programs, namely the stages of habituation, development, and learning.

\section{a. Habituation Stage}

The literacy culture programs at the habituation stage at SD Zainuddin Ngeni has been implemented well. Through this culture, students become accustomed to reading books. The implementation of literacy in class VI is carried out every morning, namely Monday, Tuesday, and Wednesday. The implementation of reading activities 15 minutes before this lesson is in accordance with regulations issued by the Ministry of Education and Culture number 23 of 2015, the habituation program carried out by schools in addition to non-lesson book literacy, also getting used to reading short letters in the Qur'an, which aims to instill religious values so that students always istiqomah in reading the Qur'an. Schools do not only focus on academics, but also try to teach character education from an early age, one of which is instilling religious values. This literacy culture at Zainuddin Ngeni Elementary School is carried out every morning before lessons and takes place consistently.

The reading strategy to foster a literacy culture at SD Zainuddin Ngeni in fifth grade is reading silently. Not only students who are seen reading, headmaster and teachers also read and are involved in monitoring the implementation of literacy in the classroom. The various reading sources used are available in the classroom reading corner. The collection of books includes fiction, traditional literature, comics, and other enrichment books. Teachers must be aware of and support the importance of self-determining the books to read to reduce student confusion (Stead, 2009:14). SD Zainuddin Ngeni does not require special books to be read. The teacher frees students to choose their own reading books according to their interests and preferences. There is no limit in reading, if you do not finish reading it will continue the next day until students can finish the book. From the results of student interviews, it was stated that literacy has a positive impact on students, with literacy, they can add new knowledge, get a lot of information, increase vocabulary, and can discuss reading books together. The results of this study are in line with research conducted by Tantri, which states that a literacy culture program that is supported by all school members is able to increase students' reading interest (Tantri\&Dewantara, 2017:6). Likewise with Ningrum's research, which revealed that through reading activities students have broad knowledge that creates curiosity or curiosity, students often ask questions when they do not understand something they read (Citra Ningrum, Fajriyah, \& Budiman, 2019: 76). From the results of research at SD Zainuddin Ngeni, it shows that implementing a school literacy culture by providing opportunities to use the time and classroom as well as possible, it will be easy to develop students' interest in reading.

\section{b. Development Stage}

The literacy culture at SD Zainuddin Ngeni in the development stage, the focus of its activities is to improve students' reading fluency and comprehension. So to measure students' understanding of reading, it is done by writing activities. This can be seen in class VI when literacy activities take place, students are asked to respond to books that have been read. The responses include writing down story elements, storylines, and writing stories in their own language in a special literacy notebook. The reading strategy at the development stage is carried out by independent reading. The implementation of literacy at Zainuddin Waru Elementary School was also accompanied by the issuance of a decree regarding the formation of a school literacy movement team that involved all class teachers as members. The results of responding to the reading book include writing, drawing, or telling orally. Students also 
expressed their pleasure and support regarding the provision of academic awards that are routinely given by teachers for student achievement and for appreciation of student literacy.

The success achieved at SD Zainuddin Ngeni can be seen from the ability of students to understand reading, namely students are able to review books that have been read and won the storytelling and writing competitions. This review activity is closely related to writing activities, so as to make students better understand reading in-depth, hone their thinking skills, and train students' ability to express opinions. This literacy culture makes the students excel, be broad-minded, and able to produce works even though they have not been published extensively. Reading various types of books allows children to recognize various forms of writing that can stimulate children's writing skills (Latham, 2012: 131). The more children read, the better their writing skills will be. This is also in line with Azis' research which reveals that literacy has an influence on writing skills, vocabulary acquisition has an impact on children's writing skills (Azis, 2017:110).

\section{c. Learning Stage}

The literacy culture in this learning uses textbook reading sources such as thematic books, and other enrichment books. Each teacher has a variety of other enrichment books that are used as a guide to deepen the material. Some of the books are privately owned and some are from the library. Meanwhile, reading sources used by students apart from the theme of books are also provided with enrichment books in the library and in the reading corner of the class, students are also given modules containing supporting materials and questions to hone students' abilities. Teachers need to instill in students about the response to books and student involvement in learning (Barlow, 2012: 3) As the result of interviews with headmaster and classroom teachers, SD Zainuddin Ngeni also conducts learning outside the classroom and is adapted to the existing material. The purpose of learning outside the classroom is so that students can add new knowledge that is not obtained through classroom learning, students also carry out information literacy and the results are collected as assignments in the form of clippings and papers. Through literacy, it is able to bridge students to continue learning and working (Sari, 2018: 96). Using the right strategy will encourage students to have metacognitive abilities so that students can find the most appropriate reading strategy according to the content of the subject matter they read. Effective teachers in teaching literacy are teachers who apply teaching techniques to how students can read, write, and develop an understanding of their knowledge (Pressley, Mohan, Raphael, \& Fingeret, 2007:222). In implementing a literacy culture in schools, as a teacher must be able to give a positive and pleasant impression to students (Bixler, Smith, \& Henderson, 2013: 252).

\section{Discussion}

According to the research finding, it shows that the implementation of literacy culture at SD Zainuddin Ngeni has implemented a literacy culture. The literacy program is guided by the Government's School Literacy Movement which is already running at the stage of habituation, development, and learning. The program is a policy carried out by schools to increase students' interest in reading. Here, the school strives to implement regulations made by the Ministry of Education and Culture of the Republic of Indonesia Number 23 of 2015 concerning the growth of character in school through habituation by reading books in 15 minutes before class every day. Then, the school has to improve facilities and infrastructure in supporting literacy activities, such as creating a text-rich environment, providing comfortable library facilities, updating book collections in libraries and reading corners. After that, the school makes social and affective environment as a literate model of communication and interaction by creating a program for organizing competitions related to literacy on national holidays, such as reading poetry, writing short stories, speech competitions, and so 
on as well as giving awards to students. The last is to make the school as a literate academic environment by reading non-lesson books, and reading Al-Qur'an. It is supported by Tantri\&Dewantara about the effectiveness literacy culture in improving students' reading interest at SDN 3 Banjar Jawa (2017: 2). While the researcher describes the implementation of literacy culture activities at SD Zainuddin Ngeni.

Moreover, based on Ningrum's research, which revealed that through reading activities students have broad knowledge that creates curiosity or curiosity, students often ask questions when they do not understand something they read (Citra Ningrum, Fajriyah, \& Budiman, 2019: 76). From the results of research at SD Zainuddin Ngeni, it shows that implementing a school literacy culture by providing opportunities to use the time and classroom as well as possible, it will be easy to develop students' interest in reading. Thus, the implementation of literacy culture activity at SD Zainuddin Ngeni has carried out three stages; First is the habituation stage. In this stage, the teacher tries to create a comfortable, calm, undisturbed atmosphere so that students can concentrate more on the books they read. Not only students who are seen reading, from the data that has been presented previously, it can be seen that the teacher also reads and supervises students, making sure everyone is reading. The headmaster is also involved in monitoring the implementation of literacy in the classroom. All school members at SDN Zainuddin Ngeni must support the implementation of literacy culture. The second is the development stage. The development stage in the high class of elementary school can carry out activities by writing responses to readings. It can be seen in fifth grade when having literacy activities. In this activity students are expected when reading a book, students are asked to write down their responses from the books they have read. The responses include writing down story elements, storylines, and writing stories in their own language in a special literacy notebook. The literacy notebooks are provided by the students themselves and the school does not provide special books or journals for literacy. The last is the learning stage. Literacy activities that have been integrated in learning, one of which is in thematic learning which contains many literacy activities. By cultivating literacy to only students in learning can be done by getting the children to read textbooks, after that the teacher asks questions about the reading. Not only asking questions, the teacher also gives assignments such as asking students to write summaries of what they read in textbooks. The goal is that students are able to write well in accordance with the rules of the language.

\section{CONCLUSION}

Based on the results of research findings and discussion, it can be concluded that: First, the literacy culture programs at SD Zainuddin Ngeni is guided by the School Literacy Movement that was created by the government on Permendikbud No. 23 of 2015. The school's policy builds a literacy culture by improving facilities and infrastructure to support literacy activities, such as creating a text-rich environment, providing comfortable library facilities, updating book collections in libraries and reading corners, forming a school literacy team as well as organizing competitions related programs with literacy on national holidays, such as reading poetry, writing short stories, speeches and so on as well as giving awards to students related to literacy achievements and awards for outstanding students. Second, the implementation of literacy culture programs at SD Zainuddin has carried out three stages, namely the habituation stage, the development stage, and the learning stage. The literacy culture program requires good cooperation and support by all school members so that it increases interest in reading and student achievement. 


\section{REFERENCES}

Abidin, Y. (2017). Pembelajaran Literasi: Strategi Meningkatkan Kemampuan Literasi Matematika, Sains, Membaca, dan Menulis. Jakarta: Bumi Aksara.

Azis, S. (2017). Implementasi Kultur Literasi Dalam Meningkatkan Kemampuan Membaca Menulis dan Berpikir Kritis Siswa SD Plus AlKausar Malang. Univ. Islam Negeri Maulana Malik Ibrahim Malang.

Barlow, D. (2012). Children's Literature in the Classroom: Engaging Lifelong Readers. Educ. Dig., 77(7), p. 71.

Bixler, J., Smith, S., \& Henderson, S. (2013). Inviting Teacher Candidates into Book Talks: Supporting a Culture of Lifelong Reading. Read Horizons, 52,(3), pp. 233-254.

Citra, N. C. H., Fajriyah, K., \& Budiman, M. A. (2019). Pembentukan Karakter Rasa Ingin Tahu Melalui Kegiatan Literasi. Indones. Values Character Educ. J., 2(2), p. 69.

Harjatanaya, T. Y., Chysta, G., \& Islamy, S. (2018). White Paper: Literasi di Indonesia. Kajian, Divisi Pendidikan, Komisi Dunia, P P I, 1-60.

Kellner, A. D., \& Share, J. (2009). Critical Media Literacy, Democracy, and the Reconstruction of Education. In D. Macedo \& S.R. Steinberg (Eds.), Media Literacy: A Reader, 3-23.

Kemendikbud. (2017). Buku Gerakan Literasi Sekolah. Direktorat Jendral Pendidikan Dasar dan Menengah. Retrieved at January 2017 from https://dikdasmen.kemdikbud.go.id.

Kemendikbud. (2019). Peraturan Menteri Pendidikan dan Kebudayaan Republik Indonesia Nomor 23 Tahun 2015 Tentang Penumbuhan Budi Pekerti, pp. 1-8.

Latham. (2012). How Children Learn to Write: Supporting and Developing Children's Writing in Schools. London: Paul Chapman.

Milles, M. B., \& Huberman, A. M. (1994). Qualitative Data Analysis. California: Sage Publication.

Muslimin. (2018). Menumbukan Budaya Literasi dan Minat Baca dari Kampung. Gorontalo: Ideas Publishing.

PISA. (2018). Indonesia What 15-year-old students in Indonesia know and can do Figure 1. Snapshot of performance in reading mathematics and science, pp. 1-10.

PISA. (2018). Results in Focus What 15-Years-Olds Know and What They Can do With What They Know. Secretary-General, OECD.

Pressley, M, Mohan L, Raphael ML, and Fingeret L. (2007). How does Bennett Woods Elementary School produce such high reading and writing achievement?. J. Educ. Psychol, 99(2), pp. 221-240.

Rostiawati, E. (2017). Membumikan Budaya Literasi di Kalangan Widyaiswara Provinsi Banten. Jurnal Lingkar Widiyaswara, 4(1), 1-6.

Sari, I. F. R. (2018). Konsep Dasar Gerakan Literasi Sekolah Pada Permendikbud Nomor 23 Tahun 2015 Tentang Penumbuhan Budi Pekerti. Al-Bidayah J. Pendidik. Dasar Islam, 10(1), pp. 89-100.

Stead, T. (2009). Good Choice: Supporting Independent Reading and Response K-6, Portland: Stenhouse Publisher.

Suragangga, I. M. N. (2017). Mendidik Lewat Literasi Untuk Pendidikan Berkualitas. Jurnal Penjaminan Mutu Lembaga Penjaminan Mutu Institut Hindu Dharma Negeri Denpasar, 3(2). Retrieved at 2 August 2017 from https://ejournal.ihdn.ac.id/index.php/JPM

Tantri \& Dewantara. (2017). Keefektifan Budaya Literasi Di SDN 3 Banjar Jawa Untuk Meningkatkan Minat Baca, Journal of Education Research and Evaluation. 1(4) pp. 204-209.

WEF. (2016). New Vision for Education: Fostering Social and Emotional With What They Know. Secretary-General, OECD. 